\title{
Paleochannel and paleohydrology of a Middle Siwalik (Pliocene) fluvial system, northern India
}

\author{
Z A KHAN ${ }^{1, *}$ and $\mathrm{R}$ C TeWARI ${ }^{2, * *}$ \\ ${ }^{1}$ Directorate of Geology and Mining, Khanij Bhawan, Lucknow 226 001, India. \\ ${ }^{2}$ Department of Geology, Sri J.N.P.G. College, Lucknow 226 001, India. \\ *e-mail: zahid26aug@yahoo.co.in \\ **e-mail: ram_tewari@yahoo.com
}

Late Cenozoic fresh water molasses sediments $(+6000 \mathrm{~m}$ thick) deposited all along the length of the Himalayan fore deep, form the Siwalik Supergroup. This paper reports the results of the paleodrainage and paleohydrology of the Middle Siwalik subgroup of rocks, deposited in non-marine basins adjacent to a rising mountain chain during Pliocene. Well-exposed sections of these rocks have provided adequate paleodrainage data for the reconstruction of paleochannel morphology and paleohydrological attributes of the Pliocene fluvial system.

Cross-bedding data has been used as inputs to estimate bankfull channel depth and channel sinuosity of Pliocene rivers. Various empirical relationships of modern rivers were used to estimate other paleohydrological attributes such as channel width, sediment load parameter, annual discharge, and channel slope and flow velocity. Computed channel depth, channel slope and flow velocity are supported independently by recorded data of scour depth, cross-bedding variability and Chezy's equation.

The estimates indicate that the Middle Siwalik sequence corresponds to a system of rivers, whose individual channels were about $400 \mathrm{~m}$ wide and 5.2-7.3 $\mathrm{m}$ deep; the river on an average had a low sinuous channel and flowed over a depositional surface sloping at the rate of $53 \mathrm{~cm} / \mathrm{km}$. The $700-\mathrm{km}$ long Middle Siwalik (Pliocene) river drained an area of $42925 \mathrm{~km}^{2}$ to the north-northeast, with a flow velocity of $164-284 \mathrm{~cm} / \mathrm{s}$, as it flowed generally south-southwest of the Himalayan Orogen. Bed-load was about $15 \%$ of the total load of this river, whose annual discharge was about $346-1170 \mathrm{~m}^{3} / \mathrm{s}$ normally and rose to approximately $1854 \mathrm{~m}^{3} / \mathrm{s}$ during periodic floods. The Froude number of 0.22 suggests that the water flows in the Pliocene river channels were tranquil, which in turn account for the profuse development of cross-bedded units in the sandstone. The estimated paleochannel parameters, bedding characteristics and the abundance of coarse clastics in the lithic fill are rather similar to the modern braided rivers of Canada and India such as South Saskatchewan and Gomti, respectively.

\section{Introduction}

In recent years, fluvial sedimentologists have carried out numerous studies to estimate quantitative hydrodynamics of ancient fluvial systems, particularly, their morphology and hydrology (Gardner 1983; Casshyap and Khan 1982; Tewari
1993; Kale et al 2004). The methods for reconstructing the morphology and hydrology employ either several groups of empirical relationships derived from modern fluvial environments or dynamic models of fluvial flow and sediment transports in alluvial reaches (Schumm 1968, 1972; Bridge 1978; Allen 1984).

Keywords. Paleochannel; paleohydrology; Siwalik; Pliocene; molasses. 
The inherent methodological problems in the input data are as follows:

- Difficulty in obtaining accurate estimates of paleochannel width and depth, and paleovelocity used as initial inputs for paleohydraulic calculations.

- Rapid expansion in error because previously estimated parameters are used in subsequent hydrological calculations.

- Appropriateness of using Schumm's empirical equations, which were developed from data on stable alluvial channels that transport a small quantity of gravels and thus, may not be equally applicable on the preserved portions of ancient fluvial systems.

In spite of these constraints, the quantitative results deduced by using similar relationships and procedures as followed by several researchers, should be of paleogeographic significance. Although the ancient fluvial Siwalik Supergroup sediments are studied for depositional environments and paleoflow characters (Kumar et al 2003; Shukla et al 2009), yet no channel morphological and paleohydrological data are available from the Pliocene fluviatile deposits of the Siwalik Supergroup of northern India. The paleochannel and paleoflow analysis is based on large-scale tough cross-beds as well as from those units of planar foresets, which have a gentle curvilinear surface and a tangential lower contact. These cross-beds are formed from migrating sub-aqueous dunes in the upper part of the lower flow regimen (Allen 1984; Sengupta 2006), because they are normally oriented within a few degrees of the flood stage current direction in the river channels (Coleman 1969; Shelton and Nobel 1974; Miall's 1976) transformation of Langbein and Leopold (1966) equation is used to estimate channel sinuosity independently from the maximum angular range of paleoflow direction. The empirical relationships developed by Schumm (1972) and reviewed by Ethridge and Schumm (1978) were then used to estimate other morphological and hydrological channel parameters during the deposition of the Middle Siwalik sequence.

\section{Geological setting, lithological and sedimentary characters}

The middle Miocene to lower Pleistocene Siwalik Supergroup is a foreland basin along the foothills of the northwestern Himalaya (figure 1). Nonmarine mudstone, shale, sandstone and boulder conglomerate of Siwalik Supergroup has a total accumulation of $+6000 \mathrm{~m}$ and represents deposition by southerly flowing river systems (Jain and Sinha 2003; Kumar et al 2003; Shukla et al 2009). The Kuluchaur area under investigation forms part of the middle Siwalik subgroup (Early Pliocene) and consists of pebbly to fine-grained sandstone with repeated intercalations of lenticular siltstone, shale and mudstone adding up to a total of $+1600 \mathrm{~m}$. This sequence of molasses deposits is a response to the late stages of tectonic activity in the Himalayan Orogenic belt and represents sediments accumulated in non-marine basins adjacent to a rising mountain chain. The vertical section commonly shows an asymmetrical fining upward sequence as deduced by quasi-independence and entropy analysis (Khan 1996), with pebbly sandstone overlain by medium- to fine-grained sandstone which in

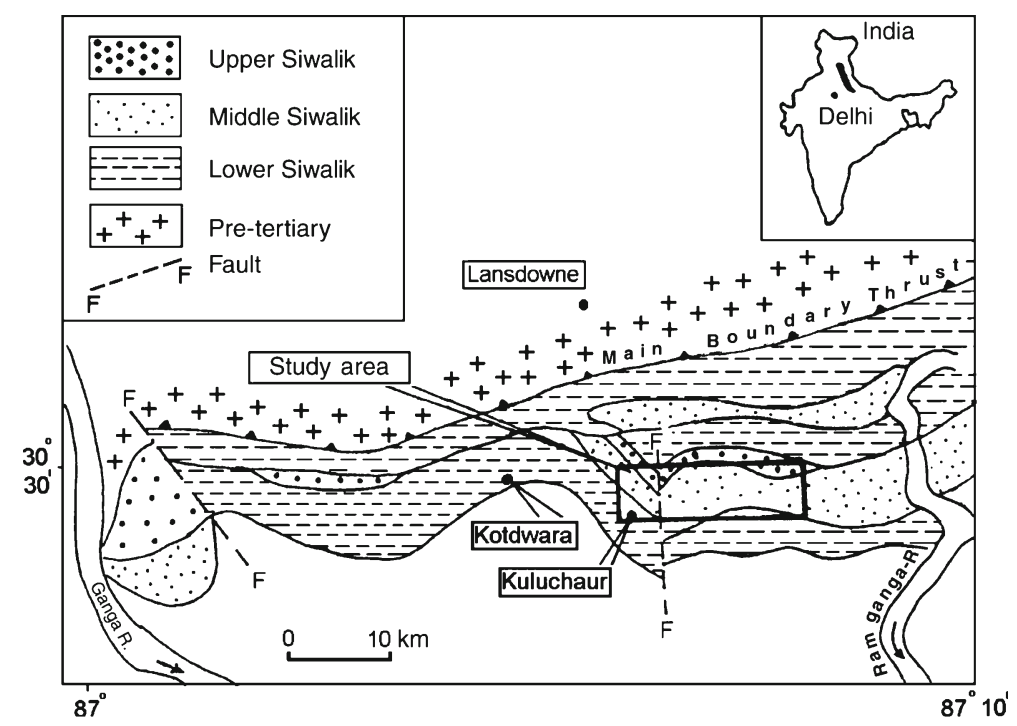

Figure 1. Sketch map of the study area including general geologic setting with major faults (after, Sahni and Mathur 1964). 
turn, is succeeded by siltstone and mudstone. The interbedded sequences made up of one or more of the above lithological elements occur repeatedly throughout the subgroup as shown diagrammatically in figure 2. In the analysis of facies sequence and bedding characteristics together with a high ratio of in-channel facies to fine-grained vertical accretion facies, the Middle Siwalik River appears to resemble a modern braided river system (Agarwal and Singh 1983; Singh and Bhardwaj 1991).

The intervals of fluvial sandstone are sheets or blankets of inconsistent lateral continuity and thickness (figure 3). Simple channel forms are relatively common. Both sheet- and channel-like bodies can be traced for several hundreds metres along the direction of regional transport. The aver- age thickness of individual sandstone bodies is $10 \mathrm{~m}$, though it may range up to $20 \mathrm{~m}$ maximum. It shows development of trough (St) and planar ( $\mathrm{Sp}$ ) cross bedding occurring in cosets and locally in single sets. These sandstones are moderately to poorly sorted, friable with calcareous cement. Sometimes the upper parts of the sandstone bodies appear to be finer grained than the lower parts. Most of the sandstone bodies are isolated from each other by thick to thin finergrained deposits of siltstone and mudstone; it is common to observe several generations of sandstone more or less intercised in the form of multilevel sand bodies. These sandstone bodies show planar cross bedding in the lower part; they are mostly capped by layers, a few decimetre in thickness $(10-50 \mathrm{~cm})$ of trough cross-beds (figure 4 ),

\begin{tabular}{|c|c|c|c|}
\hline Facies model & Facies code & Rose diagram & Statisitics \\
\hline 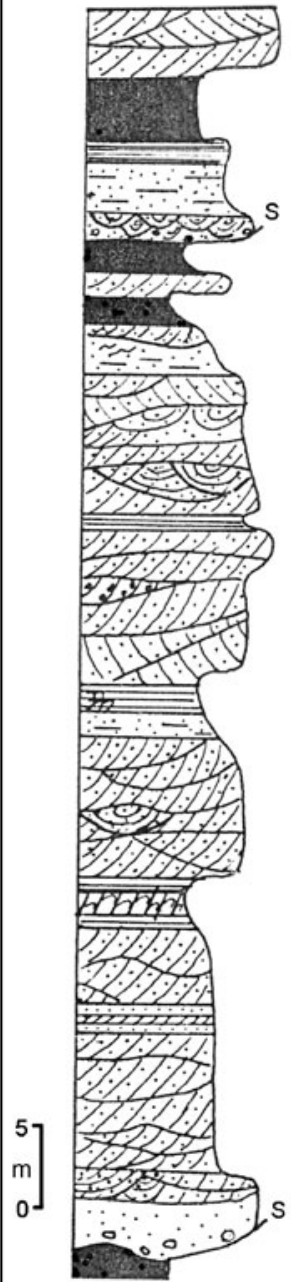 & 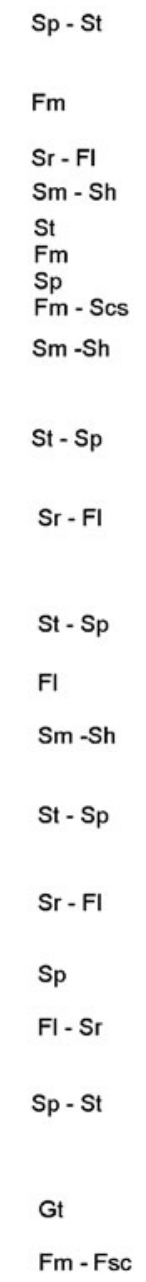 & & $\begin{array}{l}N=11 \\
\bar{\theta} \mathrm{v}=195^{\circ} \\
N=09 \\
\bar{\theta} \mathrm{v}=206^{\circ} \\
N=10 \\
\bar{\theta} \mathrm{v}=279^{\circ} \\
N=13 \\
\bar{\theta} \mathrm{v}=225^{\circ} \\
N=15 \\
\bar{\theta} \mathrm{v}=216^{\circ} \\
N=11 \\
\bar{\theta} v=160^{\circ} \\
\bar{\theta} v=182^{\circ}\end{array}$ \\
\hline
\end{tabular}

Figure 2. Rose diagrams showing frequency distribution of foreset azimuths at outcrop level. Computed statistics is recorded alongside. Facies code is: G: massive to trough cross-bedded gravelly sandstone; S: scoured surface; Sp-St: Planar and trough cross-bedded medium to coarse-grained sandstone; Sm-Sh: Massive to horizontal bedded medium to coarse sandstone; $\mathrm{Sr}-\mathrm{Fl}$ : Interbedded ripple laminated fine-grained sandstone and laminated shale; and Fm-Fsc: Massive to cross-laminated variegated fine-grained sandstone. 


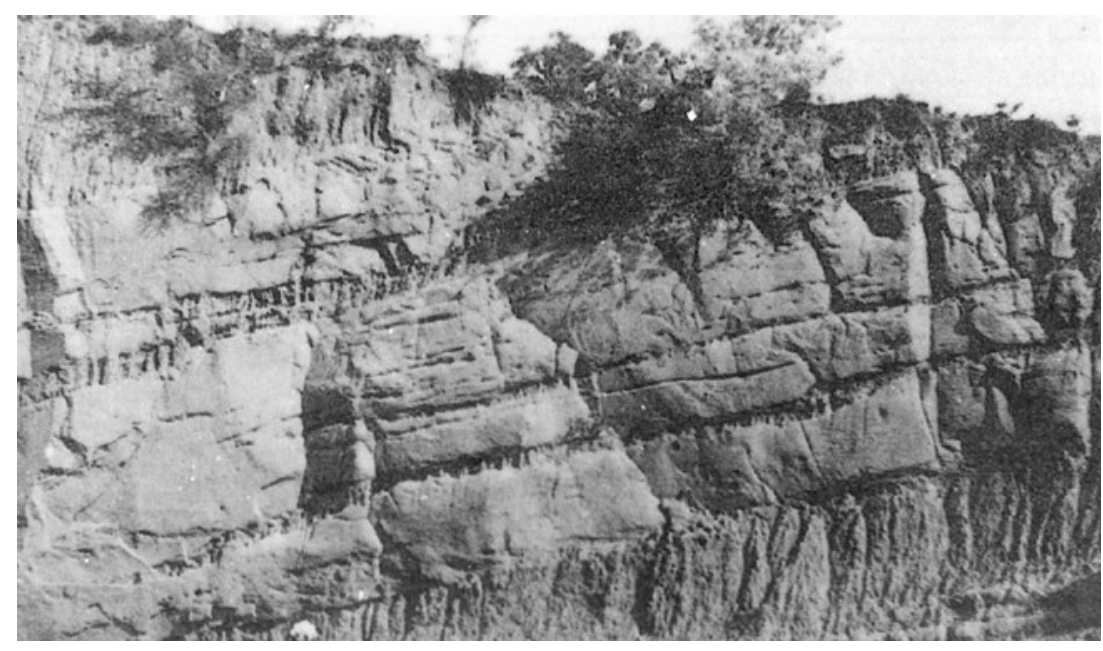

Figure 3. Coarse grained multistorey 1-m thick sandstone bodies showing scoured base and separated by a thin layer of fine mudstone.

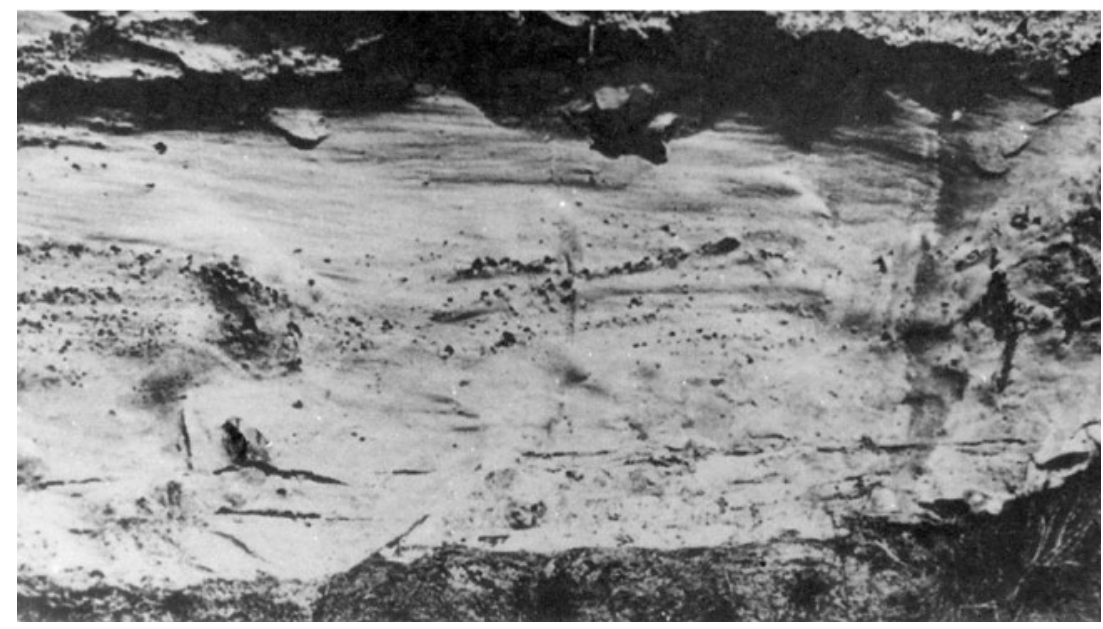

Figure 4. Trough cross-bedded medium-to-coarse grained sandstone. Clasts are present along the internal layers of troughs.

generally not very persistent laterally. The foreset laminae are clearly visible because of concentration of mica flakes along the laminae. Usually, the base of a sequence is marked by an erosive scour surface, followed by several sets of trough cross-bedded sandstone (maximum thickness of individual sets is about $80 \mathrm{~cm})$. In the basal cross-bedded set, there are concentrations of pebbles both near the base and along the foreset laminae (figure 4). Many such sequences show lateral pinching within tens of metres and are repeated within a single sandstone body. The reddish-brown mudstone bodies are about 1-8 $\mathrm{m}$ thick. Moreover, they are rather silty in nature; there are also decimetre-thick fine sandstone intercalations and some layers contain calcerete nodules. Within the silty grey fine grained sandstone (overbank facies), small ripple bedding, climbing ripples and laminated mud are common.

\section{Paleoflow characters}

Among the cross-beddings, the large scale trough (St) type has been regarded as a more reliable paleocurrent indicator than the planar ( $\mathrm{Sp}$ ) crossbeds. However, planar foresets developed side-byside with troughs, as a single set or cosets, are quite useful in the interpretation of bed forms and flow regimen conditions. Considering the above view, the foreset azimuthal data of large-scale trough as well as those units of planar cross-beds, which have a gentle curvilinear surface, recorded from the sandstone facies of the Middle Siwalik subgroup are treated statistically.

The orientation of 203 large scale cross-beds measured from 20 different beds is supplemented with a few measurements of scour channel depth. The paleoflow directions indicate a river system that flowed consistently from north-northeast to 


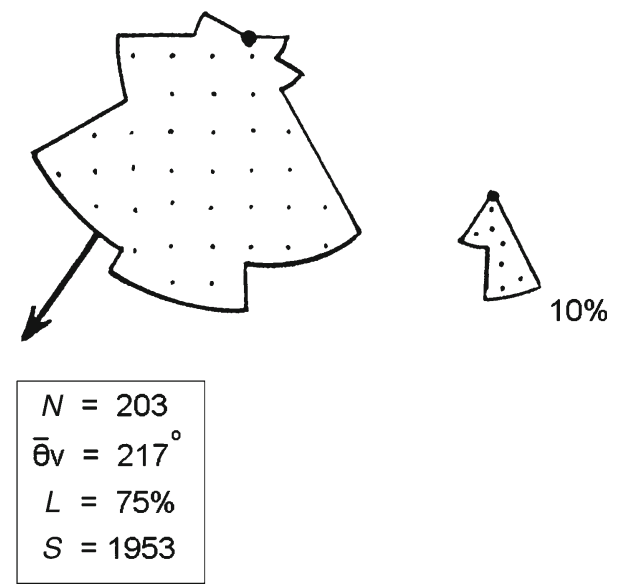

Figure 5. Rose diagram showing frequency distribution of foreset azimuth of cross-bedded Middle Siwalik sandstone at formation level with computed statistics.

south-southwest. Frequency distribution of crossbedding azimuth is plotted as rose diagrams with computed statistics shown alongside (figure 2), which exhibit unimodal and locally bimodal distribution, with the principal mode directed towards south $\left(150^{\circ}-180^{\circ}\right)$ through southwest $\left(210^{\circ}-240^{\circ}\right)$ to west $\left(270^{\circ}\right)$. The variability of the vector means probably record the shifting back and forth of channel bars in response to alleviation of the gradually subsiding basin floor.

All pooled data for the cross-bedding were also plotted as rose diagrams (figure 5) at formation level and there is no evidence of bimodality. The azimuthal data display unimodal distribution with modal class oriented towards south-southwest $\left(217^{\circ}\right)$. Furthermore, the mean paleoflow direction is not much different from those recorded at other localities to the east of the study area (Prakash et al 1974). Evidently, the paleocurrent patterns suggest a dominant role for the south-southwest-directed sediment dispersal, presumably down the regional paleoslope, which brought the sediment from the Himalayan belt.

\section{Data inputs and paleochannel morphology}

Different methods have been developed to estimate hydraulic and morphological parameters of

Table 1. Channel morphology and flow characteristics of Pliocene (Middle Siwalik) fluvial system.

\begin{tabular}{|c|c|c|}
\hline Parameters & Hydraulic equation & Estimated range \\
\hline \multicolumn{3}{|c|}{ Channel form } \\
\hline Bankfull depth & $H=0.086 D_{\mathrm{c}}^{1.19}$ & $5.2-7.3 \mathrm{~m}$ \\
\hline Bankfull width & $W=42 D_{\mathrm{bf}}^{1.11}$ & $392-572 \mathrm{~m}$ \\
\hline Sediment load & $P=0.94 M^{0.25}$ & 3.38 \\
\hline Width/depth ratio & $F=W_{\mathrm{bf} /} D_{\mathrm{bf}}$ & 75.3 \\
\hline Bed load & $S=55 / M$ & 17 \\
\hline \multicolumn{3}{|c|}{ Channel dimension } \\
\hline Mean annual discharge & $Q_{\mathrm{m}}=W_{\mathrm{bf}}^{2.43} / 18 F^{1.13}$ & $346-1169 \mathrm{~m}^{3} / \mathrm{s}$ \\
\hline & $Q_{\mathrm{m}}=V_{\mathrm{c}} A$ & $1360 \mathrm{~m}^{3} / \mathrm{s}$ \\
\hline \multirow[t]{2}{*}{ Mean annual flood } & $Q_{\mathrm{ma}}=16\left(W_{\mathrm{bf}}^{1.56} / F^{0.66}\right)$ & $1615-3998 \mathrm{~m}^{3} / \mathrm{s}$ \\
\hline & $Q_{\mathrm{ma}}=W_{\mathrm{bf}} / 2.99$ & $1653 \mathrm{~m}^{3} / \mathrm{s}$ \\
\hline \multicolumn{3}{|c|}{ Channel hydrology } \\
\hline \multirow[t]{3}{*}{ Channel sinuosity } & $P=1 /(1-\theta / 252)^{2}$ & 1.29 \\
\hline & $P=1 /(R / n)$ & 1.28 \\
\hline & $P=3.5 F^{-0.27}$ & 1.24 \\
\hline Channel slope & $S_{\mathrm{c}}=30\left(F^{0.95} / W_{\mathrm{bf}}^{0.98}\right)$ & $53 \mathrm{~cm} / \mathrm{km}$ \\
\hline \multirow[t]{3}{*}{ Flow velocity } & $V_{\mathrm{c}}=C\left(D_{\mathrm{bf}} S_{\mathrm{c}}\right)$ & $135-218 \mathrm{~cm} / \mathrm{s}$ \\
\hline & $V_{\mathrm{c}}=1.49 / n\left(D_{\mathrm{bf}}^{0.57} S_{c}^{0.50}\right)$ & $192-216 \mathrm{~cm} / \mathrm{s}$ \\
\hline & $V_{\max }=9(d)^{0.50}$ & $284 \mathrm{~cm} / \mathrm{s}$ \\
\hline Froude number & $F_{\mathrm{r}}=V_{\mathrm{c}} /\left(\mathrm{g} D_{\mathrm{bf}}\right)^{0.50}$ & 0.22 \\
\hline \multirow{4}{*}{$\begin{array}{l}\text { Drainage area } \\
\text { River length }\end{array}$} & Additional parameter & \\
\hline & $A_{\mathrm{d}}=Q_{\mathrm{m}}$ & $13725-66000 \mathrm{~km}^{2}$ \\
\hline & $L=1.4 A_{d}^{0.60}$ & $425-1090 \mathrm{~km}$ \\
\hline & $L=4.5 A_{\mathrm{d}}^{0.47}$ & $396-828 \mathrm{~km}$ \\
\hline
\end{tabular}


ancient braided and meandering rivers as summarized by Gardner (1983); at least two variables are required, the most obvious being channel width and channel depth. The sediment load parameter $(M)$, expressed as the weighted percentage of mud (finer than $0.074 \mathrm{~mm}$ ) in the channel banks, has been widely used to estimate width and depth of the ancient river channels. For the Middle Siwalik sandstone, the sediment load parameter can no longer be determined, as the matrix is largely diagenetic (Tandon 1991); nor can channel width be used because channel sections that could represent bankfull flows are not well exposed. However, sedimentary features can estimate two paleochannel attributes, namely, channel sinuosity and channel depth. Sinuosity $(P)$ has been estimated independently from maximum angular range of paleocurrent direction (Miall 1976; Tewari 2005; Khan 2011) and a reasonable estimate of channel depth $\left(D_{\mathrm{bf}}\right)$ has been made using the thickness of cross-bedded sets within a channel sandstone (Allen 1984). Using these data, regression equations as presented by Schumm (1972), equations presented by Leopold et al (1964), and graphs and equations presented by Dury (1976), a number of channel morphological and paleohydrological data are computed for the Pliocene Middle Siwalik River (table 1).

As there is considerable scatter about many of the Schumm's regression lines, it is therefore more appropriate to present a range of values for a river variable than a single value which gives no information about the possible error evolved. Graphical $95 \%$ confidence limits are estimated by using 1.96 times the standard error of the estimate given in the regression equation. Therefore, a statement of the range of values associated with each estimated variable constitutes a reliable approach for estimation of paleochannel characteristics.

\section{Channel forms}

\subsection{Estimation of bankfull depth}

The direct and most reliable method of estimating channel depth is from the thickness of stratified units of point bars (Moody-Stuart 1966; Elliot 1976) and from the average thickness of the coarse member in fining upward cycles (Jackson 1979). Frequently, point bar accretion surfaces (epsilon cross-stratified units) cannot be recognized in ancient deposits, and it has not been possible to estimate channel depth from the thickness of the coarse sand members, because of the presence of multilevel sandstone bodies and paucity of complete cycles. Alternatively, an estimate of average channel depth has been made from the thicknesses of cross-beds, as suggested by Miall (1976) using Allen's (1968) derived equation.

$$
H=0.086 D_{\mathrm{c}},
$$

where $H=$ mean ripple height and $D_{\mathrm{c}}=$ mean water depth. Thickness of cross-bedded units in the Middle Siwalik sedimentary rocks under study varies from less than $5 \mathrm{~cm}$ to about $90 \mathrm{~cm}$ but $60 \%$ of them are in the range of $20-25 \mathrm{~cm}$. The mean cross-bed set thickness is $39.4 \pm 14.6 \mathrm{~cm}$. Using the mean thickness of cross-bedded sets as ripple height $(H)$, the computed water depth varies from 4.0-5.6 m. This may correspond to the bankfull depth because the cross-beds are believed to form at flood stage. Brush (1965) from numerous observations of dune migration believes that $80 \%$ of the dunes are represented in full height by their crossstratified remnants. Regardless of the technique employed to estimate bankfull depth, two correction factors are applied to the calculated depth values from equation (1) to compensate for the following:

- compaction of sand during burial, $c$,

- variation in bankfull depth between straight and sinuous reaches, $c^{\prime}$.

A second correction is necessary as the relationships were developed by Schumm (1968, 1972), using depth measured in straight reaches of stable alluvial channels. Bankfull depth may then be estimated from

$$
D_{\mathrm{bf}}=c c^{\prime} D_{\mathrm{c}}
$$

where $D_{\text {bf }}$ is the bankfull depth, $D_{\text {c }}$ is the calculated depth from equation (1) and $c, c^{\prime}$ are defined as above. Ethridge and Schumm (1978) show that value for $c$ ranges from 1.1 to 1.2. Gardner (1983) suggested a value of 1.3 for lithic sandstone with 25-30\% ductile rock fragments. The value of $c^{\prime}$ ranges from 0.585 to 1.00 . The lower value is based on experimental flume data and may not be applicable to bed- or mixed-load rivers. These corrections are made on calculated bankfull depth in this study because sandstones of the Middle Siwalik comprise about $28 \%$ of lithic rock fragments (Gill 1985; Khan 1996). By inserting values of $c=1.3$ and $c^{\prime}=1.00$ in equation (2), the channel depth appears to be 5.2-7.3 $\mathrm{m}$ and compares well with channel scour depth measured on outcrops.

\subsection{Estimation of channel width}

A constraint in the determination of the channel morphology of an ancient river system is the lack of well-exposed point-bar sequences, which prevents direct estimation of bankfull width. Owing 
to this difficulty, Allen (1968), based on published data for lower to moderate channel sinuosity streams, worked out an alternative relationship for estimating channel width as:

$$
W=42 D_{\mathrm{bf}} .
$$

Allen (1970) further suggested that the true bankfull width in low sinuosity rivers is about two-thirds the channel widths, so that equation (3) can be read as:

$$
W_{\mathrm{bf}}=1.5\left(42 D_{\mathrm{bf}}\right),
$$

where bankfull channel width $=W_{\mathrm{bf}}$ and $D_{\mathrm{bf}}$ is bankfull channel depth. By substituting the value of $D_{\text {bf }}$ in equation (4), bankfull width is between 392 and $572 \mathrm{~m}$. Adding various bars and islands within the river, the original width of the Pliocene river may have been of the order of $0.50-0.75 \mathrm{~km}$. Agarwal and Singh (1983) reported similar channel parameters based on thicknesses of point bar sequences and sand body geometry.

\subsection{Estimation of sediment load parameter}

Schumm (1969) has developed the theory that channel morphology is controlled principally by the type of sediment load and the quantity of water moving through the channel. The sediment load parameter is represented by $M$, and is expressed as:

$$
M=\left(S c W_{\mathrm{bf}}\right)+\left(S b D_{\mathrm{bf}}\right) /\left(W_{\mathrm{bf}}+2 D_{\mathrm{bf}}\right),
$$

where $S c$ is the percentage of silt and clay in channel bed, $S b$ is the percentage of silt and clay in channel bank. $W_{\mathrm{bf}}$ is the channel width and $D_{\mathrm{bf}}$ is the bankfull channel depth.

Generally, there are two methods to estimate the sediment load parameter. In one approach, $M$ can be estimated from thin sections of sandstone (Cotter 1971; Gardner 1983). The parameter Sc and $S b$ can no longer be determined in this study because diagenesis may have completely altered the original silt-clay matrix. Also, channel width cannot be used as we have not seen any sections that could represent bankfull flow. This may cause unknown error in estimation of $M$ derived from thin section study. However, the Middle Siwalik sequence can provide a variable; channel sinuosity $(P)$, which has been reasonably estimated and an estimate of the sediment load parameter can be made by using Schumm's equation.

$$
P=0.94 M^{0.25} \text {. }
$$

If the average value of sinuosity $(P=1.27)$ is used, the sediment load parameter $(M)$ is 3.38 . The calculated value of sediment load parameter is characteristic of a bed-load channel in which the bed-load forms about $15 \%$ of the total load (Schumm 1968).

\section{Channel morphology}

\subsection{Estimation of channel sinuosity}

Sinuosity is defined as the ratio of channel length to meander axis or valley length (Brice 1964). In one approach, channel sinuosity $(P)$ has been calculated directly from the maximum range of paleocurrent directions from large scale cross-beds using formulae developed by Langbein and Leopold (1966), later modified by Miall (1976) as:

$$
P=1 /(1-\theta / 252)^{2},
$$

where $\theta$ is the mean angular variation in the orientation of cross-beds. This relationship is commonly used to deduce paleochannel sinuosity of ancient braided rivers (Casshyap and Khan 1982; Tewari 2005). In the study area, mean azimuthal direction of 70 cross-beddings ranges from $160^{\circ}-273^{\circ}$. Inserting the value of mean angular variation in the orientation of cross-beds as measured in the field; yields channel sinuosity of 1.29 well within the range of sandy bed-load river (Schumm 1968, table 1). Barrett and Fitzgerald (1985) suggested that channel sinuosity of a braided river system can approximately be estimated from the reciprocal of the vector magnitude of a set of paleocurrent directions. The sinuosity calculated in this way from the paleocurrent directions in figure 2 is 1.28 , virtually the same as that obtained from Langbein and Leopold's equation (7). A third approach popular among sedimentologists is based on the regression equation worked out from the studies of stable alluvial channels (Schumm 1972) relating channel sinuosity $(P)$ to bankfull width/depth ratio $(F)$.

$$
P=3.5 F^{-0.27} \text {. }
$$

The sinuosity so calculated yields a value 1.24 , which is about the same as deduced above. Kumar (1993) has estimated channel sinuosity of the same order $(P=1.03-1.23)$ from the Middle Siwalik sequence exposed along the southern flank of the Dehradun valley in Mohand anticline.

Studies from recent fluvial environments (Schumm 1978) indicate that channels with sinuosity value in the range $(P=1.24-1.30)$ should have width/depth ratio $>40$, and a sediment load parameter up to 5. Calculated values of these parameters in the study area lie well within the range of the established values. The prevalence of coarse channel facies and paucity of fine clastics with unimodal dispersal pattern in the resultant lithic-fill support low sinuosity values. 


\subsection{Estimating channel slope}

Channel slope of Pliocene rivers (Middle Siwalik) is estimated from a formula developed by Schumm (1972).

$$
S_{\mathrm{c}}=30 F^{0.95} / W_{\mathrm{bf}}^{0.98},
$$

where $F=$ width/depth ratio, $W_{\text {bf }}=$ channel width and $S_{\mathrm{c}}$ is the channel slope. When previously determined values of $F$ and $W_{\mathrm{bf}}$ are substituted in equation (9), the estimated channel slope is about $52.3 \mathrm{~cm} / \mathrm{km}$. The value of channel slope estimated for these Pliocene rivers compares fairly well with the measured channel slope of Recent alluvial rivers and is consistent with many ancient braided rivers (table 2).

Independently, measurement of channel slope is provided by lithic-fill, paleocurrent dispersion and the resulting sedimentary structures. Harms and Fahnestock (1965) opined that in general, large planar cross-bedding cosets and sets are most likely developed in braided, perennial rivers having steep channel slopes. In the study area, the Middle Siwalik sequences were characterized by high ratio of in-channel sandy facies to fine-grained vertical accretion facies (Khan 1996; Sharma et al 1999) and the profuse development of large-scale planar cross bedding which are interbedded with trough cross-beds having low variance. All the above characteristics thus adduced for the Middle Siwalik sequences indicate that the channel slope of the depositing rivers was steep.

\subsection{Estimating flow velocity}

The accurate determination of paleovelocity is largely dependent on obtaining a valid and reliable measure of flow resistance. In low-sinuosity, coarsegrained, high width/depth ratio channels, such as those of the Pliocene braided channel networks, bed particles are a dominant source of flow resistance. This skin resistance can be readily determined using a well-established friction coefficient for small-scale roughness channels, such as Manning's $n$. The value of Manning's $n$ for paleoflood channels is most accurately determined by computation rather by empirical methods (Maizels 1983) as follows:

$$
n=0.039 D_{50}^{0.167},
$$

where $D_{50}=50$ th percentile of the sediment size distribution.

In the study area, diameter of the median subsurface material $\left(D_{50}\right)$ varies from 0.35 to $0.84 \mathrm{~mm}$, corresponding to Manning's roughness coefficient $n$ ranging from 0.032 to 0.036 . Average paleovelocity was then estimated using the relationship:

$$
V_{\mathrm{c}}=1.49\left(D_{\mathrm{bf}}^{0.67} S_{\mathrm{c}}^{0.50}\right) / n,
$$

where $D_{\mathrm{bf}}=$ bankfull depth, $S_{\mathrm{c}}=$ channel slope and $V_{\mathrm{c}}=$ flow velocity. Substituting the respective values in equation (10), the flow velocity ranges between 2.16 and $1.92 \mathrm{~m} / \mathrm{s}$. Ethridge and Schumm (1978) however demonstrated that there is difficulty in estimating the Manning's roughness coefficient precisely. Alternatively, flow velocity can be estimated by Lacey's equation as applied by Goodwin and Deffendal (1987) for evaluating the paleovelocity of Ogallala braided streams as:

$$
V_{\mathrm{c}}=8 D_{\mathrm{bf}}^{0.60} S_{\mathrm{c}}^{0.29} .
$$

The calculated flow velocity yields a value of

\begin{tabular}{|c|c|c|c|c|c|c|}
\hline River & $\begin{array}{l}\text { Width } \\
(\mathrm{m})\end{array}$ & $\begin{array}{l}\text { Depth } \\
(\mathrm{m})\end{array}$ & Sinuosity & $\begin{array}{l}\text { Channel slope } \\
(\mathrm{cm} / \mathrm{km})\end{array}$ & $\begin{array}{l}\text { Velocity } \\
(\mathrm{cm} / \mathrm{s})\end{array}$ & $\begin{array}{c}\text { Discharge } \\
\left(\mathrm{m}^{3} / \mathrm{s}\right)\end{array}$ \\
\hline \multicolumn{7}{|l|}{ Modern river } \\
\hline Pitt (Ashley 1978) & 610 & 12.10 & 1.21 & 53 & 90 & 1800 \\
\hline Clark Fork (Deoglas 1962) & 110 & 4.10 & & 59 & 160 & 370 \\
\hline South Saskatchewan (Cant 1978) & 150 & 5.00 & 1.20 & 30 & 175 & 1240 \\
\hline Donjek (Rust 1972) & 400 & 3.00 & & 60 & 360 & 1400 \\
\hline Gomti (Kumar and Singh 1978) & 500 & 3.50 & & 54 & 150 & 2890 \\
\hline Durance (Deoglas 1962) & 660 & 6.60 & & & 600 & 280 \\
\hline \multicolumn{7}{|l|}{ Ancient river } \\
\hline Lower Feather (Barrett and Fitzgerald 1985) & 160 & 2.0 & 1.07 & 80 & 140 & 440 \\
\hline Barakar (Casshyap and Khan 1982) & 315 & 4.2 & 1.25 & 60 & 150 & 299 \\
\hline Stephanian (Padgett and Ehrlich 1976) & 192 & 3.25 & 1.16 & 23 & 40 & 500 \\
\hline Battery Powder (Cant and Walker 1976) & 467 & 5.0 & 1.03 & 29 & 120 & 280 \\
\hline Karharbari (Hota et al 2007) & 168 & 3.49 & 1.33 & 38 & 178 & 210 \\
\hline Middle Siwalik (this study) & 432 & 6.2 & 1.26 & 53 & 190 & 760 \\
\hline
\end{tabular}
$2.18 \mathrm{~m} / \mathrm{s}$ virtually same as the value deduced from equation (10).

Table 2. Comparison of paleochannel attributes of modern and ancient rivers with the Pliocene river (Middle Siwalik). 
Flow velocity can also be assessed by Chezy's equation as applied by Cant and Walker (1976) for evaluating the paleovelocity of Devonian braided rivers as:

$$
V_{\mathrm{c}}=C\left(D_{\mathrm{bf}} S_{\mathrm{c}}\right)^{0.50},
$$

where $S_{\mathrm{c}}$ is channel slope, $V_{\mathrm{c}}=$ mean flow velocity, $D_{\text {bf }}$ is the mean flow depth and $C=$ dimensional Chezy discharge coefficient, ranging from 8 to 12 for dunes. Substituting the previously calculated values of channel depth and channel slope in the above equation (12), the flow velocity is in the range $1.35-2.18 \mathrm{~m} / \mathrm{s}$, about the same as deduced above.

Pebbly to very coarse-grained units in the Middle Siwalik sequences are indicative of greater flow velocities. Several workers (Malde 1968; Turner 1978; Maizels 1983; Khan 2009) have made an estimation of threshold movement velocities using the relationship between threshold movement velocity $\left(V_{\max }\right)$ and the largest clast diameter as:

$$
V_{\max }=9(d)^{0.50},
$$

where $V_{\max }$ is the maximum flow velocity and $d$ is the diameter of the clast. The average size of the largest pebbles found embedded in pebbly sandstone bodies at various outcrops has a diameter of about $10 \mathrm{~cm}$. The threshold movement velocity to transport these clasts is in the order of $2.84 \mathrm{~m} / \mathrm{s}$, which is obviously higher than the average flow velocity calculated from equations (10, 11, and 12). Mean flow velocity deduced for Pliocene rivers are the same as that of modern rivers (table 2).

\subsection{Estimation of Froude number}

Froude number $\left(F_{\mathrm{r}}\right)$ is defined 'as the ratio between inertial force and gravitational force' (Reneick and Singh 1980; Sengupta 2006). For an open channel, flow is given as:

$$
F_{\mathrm{r}}=V_{\mathrm{c}} /\left(g D_{\mathrm{bf}}\right)^{1 / 2} .
$$

By inserting the previously determined values of $D_{\text {bf }}$, flow velocity $V_{\mathrm{c}}$ and gravitational force $g$ $\left(9.81 \mathrm{~m} / \mathrm{s}^{2}\right)$, equation (14) indicates that the Froude number for the Pliocene river was about 0.22 . The obtained value indicates that the water flow in river channels was tranquil and of lower flow regimen as substantiated by the profuse development of small- and large-scale bed forms in the sandstone bodies. Secondly, stable natural alluvial channels usually have Froude number less than 0.25 (Simons and Richardson 1971, p. 9). Furthermore, the estimated result agrees reasonably well with the graph of the Froude number versus hydraulic radius/mean fall as presented by Simons and Richardson (1971).

\section{Channel dimensions}

\subsection{Estimating mean annual discharge}

Empirical relationships between discharge and channel dimensions developed by several workers (see Kale et al 2004, for references) are employed to estimate the paleodrainage. Firstly, paleodischarge of Pliocene river is estimated by using the following equation developed by Schumm (1972).

$$
Q_{\mathrm{m}}=W_{\mathrm{bf}}^{2.43} 18 F^{1.13},
$$

where $Q_{\mathrm{m}}=$ mean annual discharge, $W_{\mathrm{bf}}=$ channel width and $F=$ width/depth ratio. When previously determined values of $W_{\mathrm{bf}}$ and $F$ are substituted, equation (15) indicates that the discharge of the Pliocene river is between 346 and $1169 \mathrm{~m}^{3} / \mathrm{s}$.

In another line of approach popular among sedimentologists is to estimate paleodischarge from the continuity equation (Gardner 1983; Khan 2009) and provide a cross check of Schumm's equation (15).

$$
Q_{\mathrm{m}}=V_{\mathrm{c}} A,
$$

where $V_{\mathrm{c}}=$ average flow velocity and $A=$ channel cross-sectional area. Channel cross-sectional area does not approximate a rectangular shape (i.e., area $=$ bankfull depth $\times$ bankfull width), as assumed by many workers. Gardner (1983) suggested a trapezoid as a better approximation of channel cross-sectional area, used in this study and can be calculated as:

$$
A=D_{\mathrm{bf}} / 2\left(2 W_{\mathrm{bf}}-\mathrm{PB}\right),
$$

where $D_{\mathrm{bf}}=$ channel bankfull depth, $W_{\mathrm{bf}}=$ channel bankfull width and PB is the horizontal extent of point bar surface. By inserting the respective values in equation (16), average paleodischarge is in the order of $1360 \mathrm{~m}^{3} / \mathrm{s}$, and similar to that calculated by equation (15).

\subsection{Estimation of mean annual flood discharge}

Schumm (1972) and Dury (1976) have presented the following formulae for the calculation of annual flood discharge for the ancient rivers as:

$$
\begin{gathered}
Q_{\mathrm{ma}}=16\left(W_{\mathrm{bf}}^{1.56} / F^{0.66}\right) \\
Q_{\mathrm{ma}}=\left(W_{\mathrm{bf}} /^{2.99}\right)^{1.81} .
\end{gathered}
$$

Using estimated values of $W_{\mathrm{bf}}$ and $F$ in equation (18), the annual flood discharge for the Pliocene (Middle Siwalik) river is in the range of 1615$3698 \mathrm{~m}^{3} / \mathrm{s}$ and $1654-3795 \mathrm{~m}^{3} / \mathrm{s}$ from Dury's equation (19), which are more or less similar. 


\section{Additional parameters}

\subsection{Estimation of drainage basin area}

Allen (1965) defined the drainage basin of a river system 'as the area enclosed by the divide separating the system from adjacent independent river system'. Leopold et al (1964), Gregory and Walling (1973) correlated mean annual flood discharge $\left(Q_{\mathrm{ma}}\right)$ with area of the drainage basin $\left(A_{\mathrm{d}}\right)$ in the following manner.

$$
Q_{\mathrm{ma}}=a A_{\mathrm{d}}^{b}
$$

where $a$ and $b$ are constants, their values depend on numerous factors including relief and climate and lie in the range $0.42-0.25$ for $a$ and $1.0-2.5$ for $b$. These values cannot be applied directly in this study owing to lack of certainty with regard to relief and climate. This relationship, therefore, has not been used. However, Eicher's (1969) formula does not take into account the questionable constant variable referred to here and is a slightly modified version of that by Leopold et al (1964) expressed as:

$$
Q_{\mathrm{ma}}=A_{\mathrm{d}} \text {. }
$$

According to this formula, area of drainage basin is approximately equal to mean annual discharge in humid regions. Cotter (1971) and Khan (1987) have applied this relationship to estimate drainage area for the rivers that deposited the Cretaceous fluvial sediments of USA and Late Paleozoic coal measures of India, respectively. In as much as humid tropical climate has been visualized during Pliocene times based on evergreen type of plants (Awasthi and Prasad 1988), if this is true, the drainage area for the Pliocene river system could be therefore approximately $42925 \mathrm{~km}^{2}$.

\subsection{Estimation of stream length}

Leopold et al (1964) and Muller (1972) derived a simple regression equation between stream length and drainage area in the following manner.

$$
\begin{aligned}
& L=1.4 A_{\mathrm{d}}^{0.64}, \\
& L=4.5 A_{\mathrm{d}}^{0.47},
\end{aligned}
$$

where $L$ is the stream length and $A_{\mathrm{d}}$ is the drainage area. Both the equations are similar and by putting the calculated values of $A_{\mathrm{d}}$ in equations $(22,23)$ indicate that the origin of the Pliocene rivers lay 395-1090 km away, presumably up the paleoslope to the north-northeast, an area now beneath the Himalayas. It is possible to test the values of stream length from field evidences. The sub-rounded to rounded pebbles from the base of Middle Siwalik sequences are a low-grade metaquartzite and granite. The rocks, which could provide these clasts, are in the crystalline zone of the central Himalayas exposed to the north and northeast, about $400 \mathrm{~km}$ away from the study area.

\section{Comparison with modern rivers}

Hydrology and channel morphology estimated for the Middle Siwalik fluvial system and comparable data compiled from modern and ancient rivers are presented in table 2. Even though the calculations for the Pliocene river are only gross estimations, if the relationships of Schumm's are applicable to conditions during Pliocene times, then it is, nevertheless, evident that the Siwalik fluvial system closely resembles those of the modern Gomti River and South Saskatchewan River of India and western Canada, respectively and many other small braided rivers (table 2). The data, however, should not be construed as representing identical fluvial systems, but rather as representative data from a relatively similar system. The size of the two systems (Gomti and South Saskatchewan) and their load are similar. It is not surprising that the calculations result in similar geomorphic and hydrologic characteristics.

Field evidences such as sand body geometry, grain size and bedding characteristics also provide other methods of assessment for the comparison with modern rivers. The grain size and bedding characteristics of the Middle Siwalik sandstones are closely comparable with sediment in the upper reaches of Gomti and South Saskatchewan rivers. Above the scoured surface, poorly defined trough cross-bed facies (St) are present in coarse-grained sandstones along with scattered pebbles (figure 5). The channels in the Gomti as well as in the South Saskatchewan rivers are floored by sinuous-crested dunes and sand bars (Kumar and Singh 1978; Cant 1978) which deposit sets of trough crossbeds. Rapid migration of sinuous-crested dunes with coarse bed-load, gives rise to poorly defined trough cross-bedding. During flood events, depth as well as flow velocity rises and coarse sediments are transported in the channels, then at low stages. The deep channel deposits, therefore, consist of trough cross-bedded coarse sandstones similar to that observed at the base of Siwalik sequences. Superimposed on the braid bars and in the channels, sinuous-crested dunes moved obliquely to the direction of movement of bars resulting in a different paleocurrent direction. The similarities in sedimentary structure and paleocurrent direction between braid bars and the direction of dunes migration of the South Saskatchewan River is striking (Cant 1978). The Pliocene river remained stabilized within a narrow zone, thus, producing several cycles of deposition. 
As the main paleoflow was diverted elsewhere, the area was in places, covered by fine-grained rippled sandstone or interbedded ripple sandstone and mudstone which occurs at or on the top of the channel sequences represents deposition in a flood plain. In the modern Gomti as well as South Saskatchewan rivers, the uppermost channel deposit consists of ripple sandstone whereas in the banks this ripple sand is overlain by muddy vertical accretion deposits of the flood plain. The mud in the flood plain of the South Saskatchewan are thicker and contain few interbeds of sand. A strong resemblance exists between the flood plain of these channels and the Siwalik muddy facies. The higher percentage of mudstone deposit in the Middle Siwalik sequences suggests that the river carried more suspended material necessary for building up a thick flood plain than observed in the Gomti and South Saskatchewan rivers. The fining upward cycles from coarse sandstone to mudstone is a product of channel filling by a single flood event (Khan 1996; Sharma et al 1999), the mudstone top forming as the river returned to its normal stages. The scale of bed forms and bed relief further strengthen the comparison between them.

Although there are clear limitations in comparing with just two modern examples, however well described, there seems to be sufficient points of similarity to justify the attempt for estimating the quantitative paleochannel parameters and hydrology of ancient Pliocene river systems. Nevertheless, a point of difference should be mentioned. The vertical burrows in the Middle Siwalik sequences appear to have no counterpart in the South Saskatchewan River, whereas vertical burrows do occur in Gomti channel sandstones (Kumar and Singh 1978). Another significant difference between the Pliocene (Middle Siwalik) and the two modern rivers lies in their respective tectonic setting. The Pliocene river system originated from uprising Himalayan Mountains in foreland basin setting, whereas the Gomti and South Saskatchewan systems are alluvial plain rivers.

These quantitative results are merely reasonable approximations that fit into the stratigraphic and geologic context in which the fluvial facies of the Middle Siwalik sequence are deposited. Nevertheless, even the less-than-exact information expands our knowledge of the Pliocene paleogeography in a way that cannot be obtained from other lines of geologic reasoning.

\section{Conclusions}

During Pliocene, in the study area, a $700 \mathrm{~km}$ long river drained an area between 13725 and $66000 \mathrm{~km}^{2}$ as it flowed generally south-southwestwards from part of the Himalayan Orogen belt. The total load transported, as bed load was about $15 \%$ suggests that the Pliocene river that deposited Middle Siwalik was of a bed load river according to Schumm's classification of alluvial channels. The discharge of Siwalik bed load river varied from $346-1169 \mathrm{~m}^{3} / \mathrm{s}$ during normal period and rose to about 1615$3700 \mathrm{~m}^{3} / \mathrm{s}$ during flood season. Water velocity of $1.92 \mathrm{~m} / \mathrm{s}$ during normal period rose to $2.16 \mathrm{~m} / \mathrm{s}$ during flood season and $2.84 \mathrm{~m} / \mathrm{s}$ during clast flow. In keeping with the characteristics of a bed load river, the channel pattern was of low sinuosity $(P=1.28)$, with a width/depth ratio $(F)$ of 75 and sediment load parameter $(M)<5$. These values are well within the range of recent braided river pattern (Schumm 1968).

As the river swept over a depositional surface sloping at the rate of $53 \mathrm{~cm} / \mathrm{km}$ through the alluvial plain in south-southwest, it was broad ( $W_{\mathrm{bf}}=$ $400 \mathrm{~m}$ ) and moderately deep $\left(D_{\mathrm{bf}}=6.0 \mathrm{~m}\right)$. Flow characteristics represent the lower part of the lower flow regimen $\left(F_{\mathrm{r}}=0.22\right)$, resulting in the development of large-scale bed forms. The estimated paleochannel parameters, dominance of coarse-grained channel fills and low paleocurrent variations indicate that the channel pattern of Pliocene river system may well correspond to a sandy bed load braided river similar to those of Gomti and South Saskatchewan rivers of India and western Canada, respectively.

As the relations for modern river determined by Schumm have not extended empirically into humid tropical regions, it is possible that some of the equations used in this study have extended beyond their range of applicability. In the authors' opinion, Schumm's equations can be applied to more humid regions because of the general validity of his principle - that the dimensions, shape, gradient and pattern of a stable alluvial river are controlled by the quantity of water and type of sediment moved through the channel.

\section{Acknowledgements}

The authors are thankful to Dr S A Farooqui, Advisor, Geology and Mining, UP for critically reading the manuscript and offering many suggestions towards its improvement. The Directorate of Geology and Mining, UP and Sri. J.N.P.G. College, Lucknow are acknowledged for working facilities. Authors also thank the reviewers of the Journal of Earth System Science for their useful suggestions.

\section{References}

Agarwal S C and Singh I B 1983 Paleoenvironment and trace fossils of the Middle Siwalik sediments, Hardwar, UP; J. Paleontol. Soc. India 28 50-55. 
Allen J R L 1965 A review of the origin and characteristics of recent alluvial sediments; Sedimentology 5 89-191.

Allen J R L 1968 Current Ripples (Amsterdam: North Holland) 433p.

Allen J R L 1970 Physical Processes in Sedimentology (London: Allen and Unwin) 248p.

Allen J R L 1984 Sedimentary structures: Their character and physical basis; Development in Sedimentology (Amsterdam: Elsevier) 30 515p.

Awasthi N and Prasad M 1988 Occurrence of Duabanga in the Siwalik sediments; Geophytology 17 292-294.

Barrett P J and Fitzgerald P G 1985 Deposition of the Lower Feaher Conglomerate - a Permian braided river deposit in southern Victorialand; Sediment. Geol. 45 189-208.

Bridge J S 1978 Paleohydraulic interpretation using mathematical models of contemporary flow and sedimentation in meandering channels; In: Fluvial Sedimentology (ed.) Miall A D, Canada Soc. Petrol. Geol. Memoir 5 723-742.

Brush C M 1965 Sediment sorting in alluvial rivers; In: Primary Structures and their Hydrodynamic Interpretation (ed.) Middleton G V, Soc. Econ. Paleontol. Mineralogists Spec. Publ. 12 25-33.

Cant D J 1978 Fluvial processes and facies sequence in the sandy braided South Sasketchewan river, Canada; Sedimentology 25 625-648.

Cant D J and Walker R G 1976 Development of a braided fluvial facies model for the Devonian Battery Point sandstone; Quebec Canada J. Earth Sci. 13 104-119.

Casshyap S M and Khan Z A 1982 Paleohydrology of Permian Gondwana streams in Bokaro basin; Bihar J. Geol. Soc. India 23 419-430.

Coleman J M 1969 Brahmaputra river: Channel processes and sedimentation; Sediment. Geol. 3 129-139.

Cotter E 1971 Paleoflow characteristics of a Late Cretaceous river in Utah from analysis of sedimentary structures in the Ferron sandstone; J. Sediment. Petrol. 41 131-138.

Dury G H 1976 Discharge prediction, present and former from channel dimensions; J. Hydrol. 30 219-245.

Eicher D L 1969 Paleobathymetry of Cretaceous Greehorn Sea in eastern Colorado; Bull. Am. Assoc. Petrol. Geol. 53 1075-1090.

Elliot T 1976 The morphology, magnitude and regimen of a Carboniferous fluvial distributary channel; J. Sedim. Petrol. 46 70-76.

Ethridge F and Schumm S A 1978 Reconstructing paleomorphological and flow characteristics; methodology, limitation and assessment; In: Fluvial Sedimentology (ed.) Miall A D, Canada Soc. Petrol. Geol. Memoir 5 705-721.

Gardner T W 1983 Paleohydrology and paleomorphology of a Carboniferous meandering fluvial sandstone; J. Sedim. Petrol. 53 991-1005.

Goodwin R G and Deffendal R E 1987 Paleohydrology of Orgallalo streams; In: Recent Development in Fluvial Sedimentology (eds) Ethridge F G, Flores R M and Harvey M D, Spec. Publ. Soc. Econ. Paleontol. Mineralogists 39 $387 \mathrm{p}$.

Hota R N, Maejima W and Mishra B 2007 River metamorphosis during Damuda sedimentation. A case study from Talchir Gondwana basin, Orissa; J. Geol. India 69 1351-1360.

Jackson R G 1979 Preliminary evaluation of lithofacies models for meandering alluvial streams; In: Fluvial Sedimentology (ed.) Miall A D, Canada Soc. Petrol. Geol. Memoir 5 543-576.

Jain V and Sinha R 2003 River systems in the Gangetic Plains and their comparison with the Siwaliks - a review; Curr. Sci. 84 1025-1033.
Kale V S, Joshi V U and Hire P S 2004 Paleohydrological reconstructions based on analysis of a paleochannel associated alluvial sediments in the Deccan Trap region, India; J. Geol. Soc. India 64 481-489.

Khan Z A 1987 Paleodrainage and paleochannel morphology of a Barakar river (Early Permian) in the Rajmahal Gondwana basin, Bihar, India; Paleogeogr. Paleoclimatol. Paleoecol. 58 237-247.

Khan Z A 1996 Quasi-independence and entropy analysis of Late Orogenic Middle Siwalik molasse sequence in Kuluchaur area, India; Geoinformatics 7 136-146.

Khan Z A 2011 Paleochannel metamorphosis in Late Paleozoic Gondwana Rivers of Peninsular India; Earth Resources and Environment (ed.) Venkatachalapatty R, Research Publishing Services Singapore (in press).

Kumar R 1993 Coalescene megafan; multistory sandstone complex of the Late-Orogenic (Mio-Pliocene) subHimalayan belt, Dehradun, India; Sedim. Geol. 85 327-337.

Kumar R, Ghosh S K and Sangode S J 2003 MiocenePliocene sedimentation history in the northwestern part of Himalayan foreland basin, India; Curr. Sci. 84 1006-1013.

Kumar S and Singh I B 1978 Sedimentological study of Gomti River sediments, U.P. India - Example of a river in alluvial plain; Senckenberg Merit 10 145-211.

Langbein W B and Leopold L B 1966 River meanders theory of minimum variance; U.S. Geol. Surv. Prof. Paper $422-\mathrm{H}$.

Leopold L B, Wolman M G and Miller J 1964 Fluvial Processes in Geomorphology (San Francisco: W H Freeman) 522p.

Maizels J K 1983 Paleovelocity and paleodischarge determination for coarse gravel deposits; In: Background to Paleohydrology (ed.) Gregroy K J (New York: John Wiley \& Sons), pp. 101-139.

Malde H E 1968 Catastropic late Pleistocene Bonnenille flood in the Snake River plains, Idaho; U.S. Geol. Surv. Prof. Paper 596.

Miall A D 1976 Paleocurrent and paleohydrologic analysis of some vertical profiles through a Cretaceous braided steams deposit. Bans Island, Canada; Sedimentology 23 459-483.

Moody-Stuart M 1966 High and low sinuosity streams deposits with examples from the Devonian of Spitsbergen; J. Sedim. Petrol. 36 1110-1117.

Muller J E 1972 Re-evaluation of the relationship of master streams to drainage basins; Bull. Geol. Soc. Am. 83 3471-3474.

Padgett G V and Ehrlich R 1976 Paleohydrologic analysis of a Late Carboniferous fluvial system, southern Morocco; Bull. Geol. Soc. Am. 87 1101-1104.

Prakash B, Bajpai I P and Saxena H P 1974 Sedimentary structures and paleocurrents of the Siwalik exposed between the Yamuna and Gola rivers; U.P. Geol. Mag. $1111-14$

Sanhi M R and Mathur L P 1964 Stratigraphy of the Siwalik Group; Proc. 22nd International Geological Congress, New Delhi, India, pp. 1-24.

Schumm S A 1968 River adjustment to altered hydrologic regimen: Murrimbidgee River and paleochannels, Australia; U.S. Geol. Surv. Prof. Paper 598.

Schumm S A 1972 Fluvial paleochannels; In: Recognition of Ancient Sedimentary Environments (eds) Rigby J K and Walton W K, Soc. Econ. Palentol. Mineralogists Spec. Publ. 16 98-107.

Schumm S A 1978 The Fluvial System (New York: John Wiley \& Sons) 338p.

Sengupta S 2006 Introduction to Sedimentology (New Delhi: Oxford and IBH Publ. Co), 314p. 
Sharma M, Sharma S, Khan Z A, Singh I B and Srivastava P 1999 Partial independence and entropy analysis of Middle Siwalik succession, Jammu area, India; Geoinformatics 10 169-185.

Shelton J W and Nobel R L 1974 Depositional features of a braided-meandering stream; Bull. Am. Assoc. Petrol. Geol. 58 742-752.

Shukla U K, Bora D S and Singh C K 2009 Geomorphic positioning and depositional dynamics of river systems in lower Siwalik basin, Kumaon Himalaya; J. Geol. Soc. India 73 335-354.

Simons D B and Richardson E V 1971 Flow in alluvial sand channels. In: River Mechanic (ed.) Shen H W, Society of
Economic Paleontologists and Mineralogists, Oklahoma, USA.

Singh A and Bhardwaj B D 1991 Fluvial facies model of the Ganga river sediments, India; Sedim. Geol. 72 $135-146$.

Tandon S K 1991 The Himalayan foredeep: Focus on Siwalik basin. In: Sedimentary Basins of India - Tectonic Context (eds) Tandon S K, Pant C C and Casshyap S M (Nainital: Gyanodaya Prakashan), Nainital pp. 171-201.

Tewari R C 2005 Fluvial facies models of Triassic Gondwana rocks of Koel-Damodar, Son and Satpura basins of eastern and central India; Gondwana Geol. Mag. 20(2) 109-118. 